\title{
"How Do You Communicate The Non-Communicable Diseases?": A Community Empowerment For Sustained Public Health
}

\author{
Dianita Sugiyo $^{1,2 *}$, Himas Surya Adikumoro ${ }^{1}$, Winda Setyadewi ${ }^{1}$, Ridwan \\ Riyadianto $^{1}$, Indah Septy Rahmawati ${ }^{1}$, Masyita Azahra1, Nurul Choiriyah ${ }^{1}$, Faudyan \\ Eka Satria ${ }^{1}$ \\ ${ }^{1}$ Faculty of Medicine and Health Sciences, Universitas Muhammadiyah Yogyakarta, Indonesia \\ ${ }^{2}$ Muhammadiyah STEPS, Universitas Muhammadiyah Yogyakarta, Indonesia \\ *dianita.sugiyo@umy.ac.id
}

\begin{abstract}
Non-Communicable Diseases (NCDs) remain the primary determinant of 36 million mortality occurring worldwide, 29 million of which occurred in developing countries. The study aims to investigate the community involvement on NCDs prevention.

This study adopted a qualitative approach, especially in applying a case study method with the structured-data collection and participatory observation and evolving in-depth interviews among stakeholders as well as a broader community. The secondary data was generated from health status and matrix from related Primary Health Center.

This research constitutes the community empowerment as one of the effective NCDs controlling strategies through several initiatives to change healthy paradigm concept. A local movement was built with the whole community contribution in raising people's health status, called Posbindu, which indicates a regular health check, health education carried by health cadres, and the distribution of healthy food made voluntarily by the village residents.

A comprehensive communication platform in extending health behavior transformation should evolve the whole community participation. The program's sustainability should be applied by The National Government to maintain the activities regularly.
\end{abstract}

Keywords : Behavioral Change, Community Empowerment, Health Communication, Health Education, Primary Health Care 


\section{STRADA Jurnal Ilmiah Kesehatan}

DOI: $10.30994 /$ sjik.v9i2.442

ISSN: 2252-3847 (print); 2614-350X (online)

Vol.9 No.2 November 2020 Page.1166-1172

\section{BACKGROUND}

Non-communicable disease (NCDs) are the primary causes of 36 million (63\%) mortality worldwide, 29 million (80\%) of which occurred in developed countries (FIP Working Group on the Role of Pharmacists in Non-Communicable Diseases, 2019). The NCDs are also responsible for 54\% of the lost of the disability-adjusted life year (DALY), including cancer, cardiovascular diseases, diabetes, neurologic, mental and behavioral conditions, and other health defects (Kruk, et. al., 2015). This condition arises as a result of changes in human behavior, and the unhealthy environment frequently appearing in lowmiddle income countries (FIP Working Group on the Role of Pharmacists in NonCommunicable Diseases, 2019; Nissinen, et. al., 2001).

The national health survey reflected that the prevalence of NCDs increased over the years, such as the prevalence of PTM increased by $0.4 \%$, the incidence of stroke increased by $3.9 \%$, the chronic renal failure cases also increased by $1.8 \%$. In contrast, the prevalence of diabetes mellitus and hypertension decreased by $1.6 \%$ and $8.3 \%$, respectively (Kementerian Kesehatan Republik Indonesia, 2018). Moreover, the statistic shows the high increase in smoking prevalence in 10 to 18 -year old youth from $7.4 \%$ in 2017 to $9.1 \%$ in 2019 (Kementerian Kesehatan Republik Indonesia, 2018).

Community empowerment and participation are two of the effective and efficient NCDs control strategies (Kruk, et. al., 2015). It can be carried out through the implementation of NCDs Integrated Health Post (Hastuti, 2019). This community-support based program resonates with the role of the community in overseeing the early detection and monitoring of significant NCDs risk factors carried out in an integrated, routine, and periodic manner (Kementerian Kesehatan Republik Indonesia, 2012). NCDs cases can be prevented by controlling risk factors, namely lifestyles, which include smoking habits, unhealthy diets, lack of physical activity, and consumption of alcoholic drinks (Nissinen, et. al., 2001). One effort to control NCDs is the empowerment and enhancement of community participation through NCDs Integrated Health Post (Kementerian Kesehatan Republik Indonesia, 2012).

\section{METHODS}

The study utilized a qualitative approach, aiming to evaluate the intent of individuals or groups in the context of social issues or human social-related problems (Mohajan, 2018). The method consisted of queries or questionnaires and procedures. The research data was gathered by using various designs, firstly, by conducting a Windshield survey to examine the environment condition of the community. The secondary data was obtained from the health record of the Primary Health Care, compiling the NCDs status of the community during the latest year period. Additionally, in-depth interviews through several group meetings were developed to gain their ideas and thoughts on the program.

\section{RESULTS}

These projects represent step to step activities, to ensure the involvement of the whole community in the program, such as; (1) Windshield Survey and detailed initial assessment. The windshield is an environmental survey to obtain social demography in health-related problems. (2) Focus Group Discussion, to generate the community ideas and perspectives towards the health problem, (3) Community crowdfunding, as a bridging program to solve the household waste problem, (4) health screening, as a way in finding new NCDs cases and health education, as a preventive knowledge resource to villagers. These two activities are designed in one movement called NCDs integrated health post. 


\section{STRADA Jurnal Ilmiah Kesehatan}

DOI: $10.30994 /$ sjik.v9i2.442

ISSN: 2252-3847 (print); 2614-350X (online)

Vol.9 No.2 November 2020 Page.1166-1172

There are several criteria measured in the health post program; the measurement of blood pressure, blood glucose level, uric acid and cholesterol level.

Table 1. Participants'gender

\begin{tabular}{llll}
\hline No. & Gender & Frequency & Percentage \\
\hline 1 & Male & 20 & 16,1 \\
2 & Female & 104 & 83,9 \\
\hline & Total & $\mathbf{1 2 4}$ & $\mathbf{1 0 0 , 0}$ \\
\hline
\end{tabular}

Resource: NCDs integrated health post - March 2020

The participants consist of 124 persons, 104 of them are female, and the rest 20 participants are male. Most the participants were women as mostly they are household wife, that staying at home during the program is held. While the male group are mostly working people.

Table 2: Participants' blood pressure

\begin{tabular}{llll}
\hline No. & Blood Pressure & Frequency $(\mathbf{n})$ & Percentage (\%) \\
\hline 1 & $<140 / 90$ & 85 & 68,5 \\
2 & $>140 / 90$ & 39 & 31,5 \\
\hline \multicolumn{2}{l}{ Total } & $\mathbf{1 2 4}$ & $\mathbf{1 0 0 , 0}$ \\
\hline
\end{tabular}

Resource: NCDs integrated health post - March 2020

About $31,5 \%$ of the participants are in the status of pre-hypertension, with the blood pressure measurement are more than $140 \mathrm{mmHg}$ for the systolic, and more than $90 \mathrm{mmHg}$ for the diastolic. While the rest of $68,5 \%$ of participants are in the status of normal blood pressure.

Furthermore, the food supplies shared during the activity were provided voluntarily by the community, which served traditionally healthy food supervised by the Nurses and assigned from the primary health center. Cadres were trained to assess general health complaints and record it in the participant's recording book. The founded NCDs cases were carried out to the primary health center or the nearest hospital for further medical assistance. Meanwhile, the health screening accommodated participants to measure their blood cholesterol, blood glucose level, and uric acid. The three tables below (table 3, table 4 , and table 5) represent each of these measurement:

Table 3. Blood glucose level $(n=71)$

\begin{tabular}{llll}
\hline No. & Blood Glucose $(\mathbf{m g} / \mathbf{d L})$ & Frequency & Percentage \\
\hline 1 & $<100$ & 22 & 31,0 \\
2 & $100-199$ & 28 & 39,4 \\
3 & $>200$ & 21 & 29,6 \\
\hline & Total & $\mathbf{7 1}$ & $\mathbf{1 0 0 , 0}$
\end{tabular}

Resource: NCDs integrated health post - March 2020

The participants with the normal blood glucose is among 31,0\% of the program population, while pre diabetic and diabetic participants counted as 28 out of 71 screened participants. There are $29,6 \%$ of the screened participants chategorised as diabetic group. 


\section{STRADA Jurnal Ilmiah Kesehatan}

DOI: $10.30994 /$ sjik.v9i2.442

ISSN: 2252-3847 (print); 2614-350X (online)

Vol.9 No.2 November 2020 Page.1166-1172

Table 4: Uric acid measurement test $(n=44)$

\begin{tabular}{llll}
\hline No. & Group & Frequency & Percentage \\
\hline 1 & Gender & & \\
& 1. Male & 5 & $11,4 \%$ \\
& 2. Female & 39 & $88,6 \%$ \\
\hline 2 & Age (y.o) & & \\
& $1.17-25$ & 1 & $2,3 \%$ \\
2. $26-35$ & 6 & $13,6 \%$ \\
3. $36-45$ & 16 & $36,4 \%$ \\
4. $46-55$ & 18 & $40,9 \%$ \\
5. 56-65 & 3 & $6,8 \%$ \\
\hline & Total & $\mathbf{4 4}$ & $\mathbf{1 0 0 \%}$ \\
\hline
\end{tabular}

Resource: NCDs integrated health post - March 2020

There are 44 participants measured for the blood uric acid level, the most frequent participant is those aged 36 to 45 years old $(36,4 \%)$ and 46 to 55 years old $(40,9 \%)$.

Table 5: Cholesterol level measurement test $(n=31)$

\begin{tabular}{llll}
\hline No. & Group & Frequency & Percentage \\
\hline 1 & Gender & & \\
& 1. Male & 4 & $12,9 \%$ \\
& 2. Female & 27 & $87,1 \%$ \\
\hline 2 & Age (y.o) & & \\
& $17-25$ & 2 & $65, \%$ \\
2. $26-35$ & 2 & $6,5 \%$ \\
3. $36-45$ & 12 & $38,7 \%$ \\
4. $46-55 \mathrm{~s}$ & 11 & $35,5 \%$ \\
5. $56-65$ & 4 & $12,9 \%$ \\
\hline & Total & $\mathbf{3 1}$ & $\mathbf{1 0 0 \%}$ \\
\hline
\end{tabular}

Resource: NCDs integrated health post - March 2020

The cholesterol group screened were 31 participants in total, with the high number on the age range of $36-45(38,7 \%)$ and 46 to $55(35,5 \%)$. The total participants screened for cholesterol level were 31 participants.

\section{DISCUSSION}

The detailed discussion of the program are defined as the followings points, representing each of the program or activities:

\section{Step 1: Windshield Survey and detailed initial assessment}

Community evaluation is a structured process that is an act of becoming acquainted with the group. The goal is to become acquainted with the environment and the population by analyzing factors that have an impact on the health of the population. The analysis helps us recognize strengths and capacities, as well as vulnerabilities and threats (Deitch, 2012). Based on the survey and also the secondary data of Primary Health Care, we found the disease frequently appearing among the people of those communities called diabetes mellitus. The case happened in 73 females (67\%) and 36 males counterparts (33\%). The second NCDs experienced by the villagers is hypertension with $62 \%$, and $38 \%$ occurring in 


\section{STRADA Jurnal Ilmiah Kesehatan}

DOI: $10.30994 /$ sjik.v9i2.442

ISSN: 2252-3847 (print); 2614-350X (online)

Vol.9 No.2 November 2020 Page.1166-1172

females and males, respectively. The determining factor of this morbidity prevalence is the lack of health information respondents' statements below:

"I seldom visit the integrated health post (Posbindu) for the elderly, I usually attend the program when I am experiencing health symptoms that requires me to join the program," (R1).

"I do not have any consideration of my eating habit (which correlates to one of the NCDs precipitating factors)," (R2).

\section{Step 2: Focus Group Discussion (FGD)}

A platform commonly used to obtain extensive social issue understanding is a focus group discussion (Nyumba, et. al., 2018). The selected involved participants of this FGD are based on their social roles in the village, mainly as stakeholders and decision-makers in the community, such as the health cadres, village leaders, youth group representatives, household mothers, and the primary health care delegations. There were two FGDs organized during the program. First, it was focused as an introduction phase to the community, followed by an initial assessment of the general problems raised among the people. Upon completing a Windshield survey, the second FGD was administered to present the survey findings followed by a discussion to seek community aspiration in solving the problems of community empowerment. The last FGD concluded three major programs; community crowdfunding, health screening, and health education program.

\section{Step 3: Community crowdfunding}

Generally, in the context of low-middle income countries, solid waste management is an essential factor influencing the state of the natural environment and community lives (Sinthumule \& Mkumbuzi, 2019). The project starts with the presence of a waste management problem in the community, resulting in trash burning and causing the new air pollution problem. The waste accumulation also led to further issues when the rainy season comes, as the number of high dengue fever reported increased in those populations. On the other hand, the health initiative built by the community (integrated development post) required a sustained financial resource to run in providing meals and other nutritious diets for the program attendees. Furthermore, the public complied to set a community-based project in the solid waste management that further returned the additional financial income to the families. The project ranged from waste sorting, from recycled to organic, waste transportation to the local waste collectors, and the return of the revenue to the community and family benefits.

\section{Step 4: NCDs integrated health post}

The health screening program was conducted to be integrated with the NCDs health post-in-line with health education, which was scheduled monthly by involving cadres and primary health workers. The NCDs health post consisted of five activities, namely participants registration, body weighting, blood pressure measurement, health education and screening, and nutritious food distribution. The two tables below (table 1 and table 2) represent the participants and their blood pressure during the program in March 2020.

This NCDs integrated health post represented a solid collaboration among villagers hand in hand to fulfill the health-supporting needs of the vulnerable groups. This characteristic of community networking is needed to increase the supply of healthy food, aiming to minimize the consumption of processed foods and provide a healthy balanced diet (Ministry of Health Brazil, 2011). In each monthly program, the health cadres were 


\section{STRADA Jurnal Ilmiah Kesehatan}

DOI: $10.30994 /$ sjik.v9i2.442

ISSN: 2252-3847 (print); 2614-350X (online)

Vol.9 No.2 November 2020 Page.1166-1172

supported by medical consultation and health aid measurement tools from the local primary health center. These medical logistics were free, financed by the local health office. One of the critical factors for a successful community-based intervention is to accommodate a strong leadership in ensuring the right system deliveries for the project (Asia Pacific Economic Cooperation Health Working Group, 2014). Additionally, the importance of accomodating the local counterpart capacity building on basic essential health assessment skills was another vital strategy (World Health Organization, 2013).

\section{CONCLUSION}

The NCDs, which continue as a significant health problem, are related to people's lifestyles and their health literacy. The implementation and action taken to figure out this community behavioral problem should concern on the sustained program, which can represent the community involvement through an empowerment movement. This study suggests all related stakeholders to identify how to modify the problem to be a resilientresources for the community

\section{REFERENCES}

FIP Working Group on the Role of Pharmacists in Non-Communicable Diseases. (2019). Beating non-communicable diseases in the community: The contribution of pharmacists. Downloaded at April 25 $5^{\text {th }} 2020$ from https://www.fip.org/files/content/publications/2019/beating-ncds-in-thecommunity-the-contribution-of-pharmacists.pdf.

Kruk, M. E., Nigenda, G., \& Knaul, F. M. (2015). Redesigning primary care to tackle the global epidemic of noncommunicable disease. American Journal of Public Health, 105(3), pp.431-437.

Nissinen, A., Berrios, X., Puska, P. (2001). Community-based noncommunicable disease interventions: Lessons from developed countries for developing ones. Bull World Health Organization, 79(10), pp.963-970.

Sinthumule, N. I. \& S. H. Mkumbuzi. (2019). Participation in community-based solid waste management in Nkulumane Suburb, Bulawayo, Zimbabwe. Resources, 8(1), pp.30.

Kementerian Kesehatan Republik Indonesia. (2018). Hasil Utama RISKESDAS. Downloaded at June $17^{\text {th }} \quad 2020$ from https://www.kemkes.go.id/resources/download/info-terkini/hasil-riskesdas2018.pdf.

Hastuti N. M., Pupitasari R., \& Sugiarsi S. (2019). Peran Kader Kesehatan Dalam Program Posbindu Penyakit Tidak Menular Di Puskesmas Jateng. Jurnal Ilmiah Maternal, 3(2), pp.57-61.

Kementerian Kesehatan Republik Indonesia. (2012). Petunjuk Teknis Pos Pembinaan Terpadu Penyakit Tidak Menular (Technical Guidelines to Posbindu of uninfectious disease) (Posbindu PTM). Downloaded at April 25 2020 from http://p2ptm.kemkes.go.id/uploads/2016/10/Petunjuk-Teknis-Pos-PembinaanTerpadu-Penyakit-Tidak-Menular-POSBINDU-PTM-2013.pdf.

Mohajan, H. (2018). Qualitative Research Methodology in Social Sciences and Related Subjects. Journal of Economic Development, Environment and People, 7(1), pp.2348.

Deitch, P. 2012. Windshield Survey. Downloaded at April $25^{\text {th }} 2020$ from http://publichealth.casn.ca/content/user_files/2015/06/Windshield-Survey- 


\section{STRADA Jurnal Ilmiah Kesehatan}

DOI: $10.30994 /$ sjik.v9i2.442

ISSN: 2252-3847 (print); 2614-350X (online)

Vol.9 No.2 November 2020 Page.1166-1172

document-assignment.pdf.

Nyumba, T. O., Wilson, K., Derrick, C. J., \& Mukherjee, N. (2018). The use of focus group discussion methodology: Insights from two decades of application in conservation. Methods Ecol Evol. 9(1), pp.20-32.

Ministry of Health Brazil. (2011). Strategic Action Plan to Tackle Noncommunicable Diseases (NCD) in Brazil 2011-2022. Downloaded at April 25 2020 from https://www.iccp-portal.org/system/files/plans/BRA_B3_Plano\%20DCNT\%20$\% 20$ ingl\%C3\%AAs.pdf

Asia Pacific Economic Cooperation Health Working Group. (2014). Framework on Community Based Intervention to Control NCD Risk Factors. Downloaded at April $25^{\text {th }}$ from 2020 https://apec.org/-/media/APEC/Publications/2014/8/Framework-onCommunity-Based-Intervention-to-Control-NCD-Risk-

Factors/FRAMEWORKS_ForPrint_OKE_2.pdf

World Health Organization. (2013). Global Action Plan. Downloaded at April 25 2020 https://www.who.int/iris/bitstream/10665/94384/1/9789241506236_eng.pdf?ua=1 